Jurnal Media Agribisnis Vol. 4 No. 1 Tahun 2019 Hal 1 - 9

Media Komunikasi Hasil Penelitian Bidang Ilmu Agribisnis

ISSN print 2548-7027

ISSN online 2541-6898

\title{
PENDAPATAN PENGOLAH LIMBAH USAHA TERNAK SAPI DI KECAMATAN BATANG ASAM KABUPATEN TANJUNG JABUNG BARAT
}

\author{
${ }^{1)}$ Nida Kemala ${ }^{1}$ dan ${ }^{2)}$ Dwi Arum Sekartika S \\ ${ }^{1)}$ Dosen Program Studi Agribisnis, Fakultas Pertanian Universitas Batanghari \\ ${ }^{2)}$ Alumni Program Studi Agribisnis, Fakultas Pertanian Universitas Batanghari \\ Jl. Slamet Riyadi-Broni, Jambi. 36122. \\ ${ }^{1)}$ Email korespondensi : nida.kemala@unbari.ac.id
}

\begin{abstract}
Sri Agung Village, which is located in Batang Asam District West Tanjung Jabung Regency is the only one location that has a high technology cattle manure processing to be a biogas. The aim of this research was to find out the process description, cost and income of that cattle manure processing. The results of this research was indicated that the manure was collected manualy by only two workers. The processing of livestock waste carried out manually. The products (except biogas) were sold out within 3 month. There were 4 types of product in this livestock farm e.g. fresh catle manure, biogas, dry and wet of biogas by product. Biogas processing was started by inserting a mixing of manure and water (1:1). The appearance Methane gases then would be flowed to the stove as fuel. While its by product such as its dry and wet waste were sold respectively as $R p .1000 / \mathrm{Kg}$ and $\mathrm{Rp}$. 10.000/liter. In quarterly periode, revenues received in this catle livestock farm by product amounts to Rp 9.270 .000 and total costs as $R p$ 1.105.391,58 so that the income was $R p$ 8.159.509,64.
\end{abstract}

Keyword : biogas, manure, by product

\begin{abstract}
Abstrak
Desa Sri Agung yang terletak di Kecamatan Batang Asam, Kabupaten Tanjung Jabung Barat adalah satu-satunya lokasi yang memiliki teknologi pengolahan limbah ternak sapi menjadi biogas. Tujuan dari penelitian ini adalah untuk menggambarkan proses, biaya dan pendapatan dalam pengolahan kotoran sapi. Hasil penelitian ini pengumpulan kotoran sapi dilakukan secara manual oleh 2 orang pekerja. Penjualan hasil produksi dilakukan dalam 3 bulan sekali. Terdapat 4 jenis hasil pengolahan limbah usaha ternak sapi yaitu kotoran segar, biogas, limbah biogas kering, dan limbah biogas cair. Pengolahan biogas diawali dengan memasukkan campiran kotoran ternak sapi dengan air (1:1). Gas metan yang terbentuk akan mengalir ke kompor sebagai bahan bakar. Sedangkan limbah biogas dalam bentuk cair dan kering dijual masing-masing dengan harga Rp.1000/kg dan Rp 10.000/liter. Dalam periode triwulan penerimaan pada produk sampingan dari usaha peternakan sapi ini adalah sebesar Rp 9.270.000 dan total biaya dalam triwulan sebesar $\mathrm{Rp} 1.105 .391,58$ maka pendapatan yang diterima dalam triwulan sebesar Rp 8.159.509,64.
\end{abstract}

Kata Kunci : Biogas, feses, limbah

Diterbitkan oleh Program Studi Agribisnis Fakultas Pertanian Universitas Batanghari Jambi Halaman 1 
Jurnal Media Agribisnis Vol. 4 No. 1 Tahun 2019 Hal 1 - 9

Media Komunikasi Hasil Penelitian Bidang Ilmu Agribisnis

ISSN print 2548-7027

ISSN online 2541-6898

\section{PENDAHULUAN}

Di Indonesia sentra produksi sapi potong tersebar hampir di seluruh wilayah nusantara dengan skala yang bervariasi mulai dari skala rumah tangga dengan jumlah sapi kurang dari lima ekor, hingga skala perusahaan dengan ribuan ekor sapi (Muhamad Agus Setiadi et all 2012). Populasi sapi di Indonesia mencapai 16,5 juta ekor dan Provinsi Jambi memiliki populasi sapi sebanyak 156.000 ekor pada tahun 2017 ( Badan Pusat Statistik 2017). Keberadaan peternakan tidak lepas dari limbahnya yang memerlukan perhatian khusus untuk bias dimanfaatkan. Limbah ternak adalah sisa buangan dari suatu kegiatan usaha peternakan. Limbah tersebut meliputi limbah padat dan limbah cair seperti feses, urin, sisa makanan, embrio, kulit telur, lemak, darah, bulu, kuku, tulang, tanduk, isi rumen (Sihombing, 2000). Limbah peternakan meliputi semua kotoran berupa limbah padat, cair, gas ataupun sisa pakan (Soehadji, 1992). Banyak manfaat dari kotoran sapi sebagaimana disampaikan oleh Brady (1974) dalam Sudarkoco, (1992) yang menyatakan bahwa kotoran sapi merupakan bahan organik yang secara spesifik berperan meningkatkan ketersediaan fosfor dan unsur-unsur mikro, mengurangi pengaruh buruk dari alumunium, menyediakan karbondioksida pada kanopi tanaman, terutama pada tanaman dengan kanopi lebat dimana sirkulasi udara terbatas. Kotoran sapi banyak mengandung hara yang dibutuhkan tanaman seperti nitrogen, fosfor, kalium, kalsium, magnesium, belerang dan boron. Limbah padat adalah semua limbah yang berada dalam fase padat. Limbah cair adalah semua limbah yang berada dalam fase cair. Limbah gas adalah semua limbah yang berada dalam fase gas (Wahyuni dan Sri 2009).

Pemanfaatan limbah sapi menjadi pupuk organik merupakan peluang untuk meningkatkan pendapatan dan meringankan pengeluaran khususnya penggunaan gas LPG para keluarga peternak selain itu juga dapat digunakan untuk perbaikan lahan pertanian yang telah rusak. Untuk itu perlu konsep yang mampu mengubah pola pikir peternak bahwa feces dan urine yang dihasilkan ternak sapi mereka adalah sumber tambahan pendapatan apabila diolah lebih lanjut.

Biogas merupakan energi alternatif yang banyak manfaat. Biogas dapat menghemat gas alam, hasil sampingan biogas yang terbuat dari kotoran hewan dapat dimanfaatkan menjadi pupuk. Biogas juga sebagai salah satu jenis bioenergi yang didefinisikan sebagai gas yang dilepaskan jika bahan-bahan organik seperti kotoran ternak, kotoran manusia, jerami, sekam dan daun-daun hasil sortiran sayur difermentasi atau mengalami proses metanisasi (Hambali E et all., 2008). Mulai sekarang pengembangan energi biogas dari kotoran sapi dikembangkan oleh pemerintah dengan cara melakukan pelatihan di beberapa daerah dan memperbanyak reaktor penghasil biogas dari kotoran hewan. Biogas memiliki beberapa keuntungan seperti: dapat mengurangi emisi gas rumah kaca, mengurangi bau yang tidak sedap, mencegah penyebaran penyakit, menghasilkan pupuk dan energi. Pemanfaatan limbah seperti ini secara ekonomi sangat kompetitif seiring naiknya harga bahan bakar minyak dan pupuk anorganik. Sasaran pengembangan teknologi biogas untuk menangani limbah agroindustri diharapkan dapat memberikan nilai tambah ekonomi dan

Diterbitkan oleh Program Studi Agribisnis Fakultas Pertanian Universitas Batanghari Jambi Halaman 2 


\section{Jurnal Media Agribisnis Vol. 4 No. 1 Tahun 2019 Hal 1 - 9}

Media Komunikasi Hasil Penelitian Bidang Ilmu Agribisnis

ISSN print 2548-7027

ISSN online 2541-6898

perbaikan lingkungan hidup. Sisa biogas berupa kotoran ternak yang telah hilang gasnya (slurry) merupakan pupuk organik yang sangat kaya akan unsur-unsur yang dibutuhkan oleh tanaman. Unsur-unsur tertentu yang terdapat sisa biogas seperti protein, selulose, lignin, dan lain-lain tidak bisa digantikan dengan pupuk kimia. Selain sisa biogas terapat juga kotoran ternak sapi basah, kotoran ternak sapi basah berupa kotoran ternak yang tidak di olah (Haryati 2006).

Kabupaten Tanjung Jabung Barat merupakan kabupaten yang memiliki ternak sapi yang terbilang cukup banyak pada tahun 2015 mencapai 7193 ekor sapi. Kecamatan Batang Asam merupakan satu-satunya Kecamatan di Kabupaten Tanjung Jabung Barat yang memiliki pengolahan limbah ternak sapi, tepatnya di Desa Sri Agung Dengan adanya teknologi pengolahan limbah ternak sapi, maka limbah yang biasanya hanya dibiarkan begitu saja kini dapat diolah dan bisa menghasilkan pendapatan tambahan. Berdasarkan uraian di atas maka peneliti tertarik untuk meneliti tentang "Pendapatan Pengolah Limbah Ternak Sapi Kecamatan Batang Asam Kabupaten Tanjung Jabung Barat".

\section{METODOLOGI PENELITIAN}

Penelitian ini dilaksanakan di Desa Sri Agung, Kecamatan Batang Asam, Kabupaten Tanjung Jabung Barat. Daerah lokasi penelitian ini diambil secara sengaja (purposive) dengan pertimbangan bahwa desa ini merupakan desa yang memiliki peternakan sapi sistem pemeliharaan yang dilengkapi dengan teknologi pengolahan limbah ternak sapi menjadi biogas.

Jenis data yang digunakan yaitu data Time Series ( 2 triwulan terakhir ) dan berskala ukur rasio, serta dilengkapi data primer dan sekunder. . Jangka waktu triwulan diambil karena masa penjualan di lokasi penelitian dilakukan dalam jangka waktu 3 bulan sekali, Data primer diperoleh melalui wawancara langsung dengan responden yang dipandu dengan daftar pertanyaan (kuisioner) yang telah disediakan terlebih dahulu sesuai dengan tujuan peneliti. Sedangkan data sekunder diperoleh dari instansi atau lembaga terkait serta hasil-hasil penelitian yang berhubungan dengan penelitian ini. Data dikumpulkan dengan metode survey.

Data yang diperoleh dari hasil penelitian dianalisis secara deskriftif baik secara kualitatif maupun kuantitatif. Untuk menganalisa besarnya pendapatan maka perlu diketahui terlebih dahulu besarnya biaya total dan penerimaan. Biaya total diketahui dengan mendata pengunaan input dan menghitung biaya produksi yang dikeluarkan dalam usaha tersebut. Lebih lanjut untuk menghitung besarnya jumlah biaya produksi dengan cara menjumlahkan total biaya tetap atau total fixed dengan total biaya tidak tetap atau total variable, sesuai dengan rumus sebagai berikut (Sudarman dan Algifari, 2001):

Keterangan:

$$
\mathbf{T C}=\mathbf{T F C}+\mathbf{T V C}
$$

TC $=$ Total Cost atau total Biaya (Rp/Triwulan)

TFC = Total Fixed cost atau Total Biaya Tetap (Rp/Triwulan)

TVC = Total Variable Cost atau Total Variabel (Rp/Triwulan)

Diterbitkan oleh Program Studi Agribisnis Fakultas Pertanian Universitas Batanghari Jambi Halaman 3 


\section{Jurnal Media Agribisnis Vol. 4 No. 1 Tahun 2019 Hal 1 - 9}

Media Komunikasi Hasil Penelitian Bidang Ilmu Agribisnis

ISSN print 2548-7027

ISSN online 2541-6898

Dalam hal ini Total Cost atau total Biaya dihitung berdasarkan nilau penyusutan berbagai sarana yang terpakai. Untuk menghitung besarnya biaya penyusutan tersebut digunakan rumus metode garis lurus sebagai berikut (Sudarman dan Algifari, 2001):

Keterangan:

$$
\mathbf{D}=\frac{\mathbf{P}-\mathbf{S}}{\mathbf{N}}
$$

$$
\begin{array}{ll}
\mathrm{D} & =\text { Nilai Penyusutan }(\mathrm{Rp} / \text { Triwulan }) \\
\mathrm{P} & =\text { Nilai Awal Alat }(\mathrm{Rp}) \\
\mathrm{S} & =\text { Nilai Akhir Alat }(\mathrm{Rp}) \\
\mathrm{N} & =\text { Perkiraan Umur Ekonomis (Triwulan) }
\end{array}
$$

(Asumsi : Harga akhir alat $=$ nol)

Setelah biaya total diketahui selanjutnya perlu ditentukan jumlah penerimaan yang merupakan nilai jual dari hasil produk, sebagaimana Sudarman dan Algifari, (2001) merumuskan sebagai berikut :

$$
\mathbf{T R}=\mathbf{P q} \cdot \mathbf{Q}
$$

Keterangan:

$$
\begin{array}{ll}
\mathrm{TR} & =\text { Total Revenue Atau Total Penerimaan }(\mathrm{Kg} / \text { Triwulan }) \\
\mathrm{Pq} & =\text { Price Prouct Atau Harga Produk }(\mathrm{Rp} / \text { Triwulan }) \\
\mathrm{Q} & =\text { Total Production Atau jumlah Produksi }(\mathrm{Kg} / \text { Triwulan })
\end{array}
$$

(Catatan : Asumsi semua hasil produksi dijual)

Bila dua variable yaitu biaya total dan penerimaan telah ditentukan selanjutnya menentukan pendapatan yang menurut Boediono (1992) pendapatan ini diperoleh dengan cara melihat selisih antara total penerimaan dan total biaya, dengan rumus sebagai berikut:

$$
\mathbf{I}=\mathbf{T R}-\mathbf{T C}
$$

Keterangan:

$$
\begin{array}{ll}
\mathrm{I} & =\text { Income Atau Pendapatan (Rp/Triwulan) } \\
\mathrm{TR} & =\text { Total Revenue Atau total penerimaan (Rp/Triwulan) } \\
\mathrm{TC} & =\text { Total Cost Atau total biaya (Rp/Triwulan) }
\end{array}
$$

\section{HASIL DAN PEMBAHASAN}

\section{Gambaran Pengolahan Limbah Ternak Sapi}

Pengolahan limbah ternak sapi memerlukan peralatan sebagai berikut : cangkul, skop, galon, selang, ember, dan drum. Selain itu juga memerlukan sarana seperti, rumah kompos dan tangki biogas. Alat-alat tersebut berasal dari pembelian oleh pengolah limbah ternak sapi. Modal yang digunakan dalam 
Jurnal Media Agribisnis Vol. 4 No. 1 Tahun 2019 Hal 1 - 9

Media Komunikasi Hasil Penelitian Bidang Ilmu Agribisnis

ISSN print 2548-7027

ISSN online 2541-6898

pengolahan limbah ternak sapi yaitu modal sendiri dari hasil tabungan. Lahan yang digunakan untuk pengolahan limbah ternak sapi berstatus lahan sendiri.

Salah satu limbah yang ada dalam peternakan sapi ini adalah kotoran segar yang masih memiliki nilai jual. Proses pengumpulan limbah ternak sapi dilakukan secara manual dengan skop. Limbah ternak sapi dikumpulkan setiap hari pada saat pagi hari dengan jumlah tenaga kerja 2 orang yang terdiri dari pemilik peternakan itu sendiri dan istrinya. Selain dijual dalam keadaan segar limbah ini juga masih bisa diolah sebagai bahan baku dalam menghasilkan biogas. Hasil sampingan dari pengolahan biogas ini adalah limbah biogas kering, dan limbah biogas cair yang juga masih bernilai ekonomis untuk dijual. Limbah ternak sapi yang tidak dijadikan biogas dijadikan kompos dengan mencampurnya dengan sisa pakan lalu diberikan dekomposer. Pada volume 200ml/M3 campuran bahan-bahan tersebut dimasukkan ke dalam karung dan diikat untuk difermentasi selama 21 hari menjadi pupuk kompos. Kompos yang dihasilkan mencapai kuantitas sebesar \pm $1.134 \mathrm{Kg} /$ Triwulan yang dijual dengan harga $\mathrm{Rp} .500 / \mathrm{Kg}$.

Lain halnya dengan pengolahan biogas yang dilakukan hanya dengan memasukkan kotoran ternak sapi ke dalam tangki biogas dan ditambahkan air dengan perbandingan 1:1 (kotoran sapi dengan air). Hal ini biasa dilakukan setiap pagi dan sore. Di dalam tangki biogas terjadi proses fermentasi oleh banyak mikroba menghasilkan gas metan yang akan dimanfaatkan untuk pengganti bahan bakar memasak di dapur yang biasanya menggunakan tabung Gas LPG $3 \mathrm{~kg}$.

Selain menghasikan gas metan, proses pengolahan biogas ini juga menyisakan limbah berupa limbah biogas cair dan limbah biogas padat. Dalam hal ini limbah biogas cair yang diperoleh lalu dimasukkan ke dalam kemasan jerigen untuk dijual dengan harga Rp. 10.000/liter. Sedangkan limbah biogas kering dijual dalam kemasan karung dengan harga Rp. 1000/kg. Sistem penjualan limbah baik limbah biogas cair maupun kering tersebut dilakukan dengan cara sistem jemput oleh konsumen langsung.

\section{Biaya Produksi Pengolahan Limbah Ternak Sapi}

Biaya produksi yaitu jumlah total biaya yang dikeluarkan dalam pengelolaan peternakan sapi yang terdiri dari biaya tetap dan biaya variabel. Biaya tetap merupakan biaya yang besarnya tidak terkait langsung dengan tingkat hasil produksi atau biaya yang dikeluarkan untuk sarana/bahan yang penggunaannya tidak habis dalam satu kali proses produksi. Sedangkan biaya variabel adalah biaya yang besarnya berubah dan terkait langsung dengan tingkat hasil produksi atau biaya yang dikeluarkan untuk sarana/bahan yang penggunaannya habis dalam satu kali proses produksi.

Total biaya produksi pengelolaan limbah ternak sapi adalah Rp.1.100.293/Triwulan. Biaya tersebut berasal dari biaya produksi kompos (Rp.535.573,69/Triwulan) dan pengolahan biogas (Rp. 564.719,31/Triwulan). Dalam hal ini terdapat dua sarana yang dipakai secara bersama-sama (cangkul dan skop) yaitu dalam pembuatan kompos juga dalam proses pembuatan biogas. Biaya tersebut adalah sebesar Rp.10.197.36/Triwulan sehingga masing-masing kegiatan tadi mengeluarkan biaya tetap sebesar Rp. 5.098,68/Triwulan dimana biaya 


\section{Jurnal Media Agribisnis Vol. 4 No. 1 Tahun 2019 Hal 1 - 9}

Media Komunikasi Hasil Penelitian Bidang Ilmu Agribisnis

ISSN print 2548-7027

ISSN online 2541-6898

tersebut tersebar untuk masing-masing cangkul dan skop (Rp.3.125/Triwulan dan Rp. 1.973,68/Triwulan). Biaya tetap terbesar digunakan untuk pengadaan Bak pelengkap tangki biogas yang terbuat dari fiber dengan biaya sebesar Rp.135.000/Triwulan dan biaya yang terkecil terlihat dialokasikan untuk biaya pengadaan bak semen biogas yaitu sebesar Rp 2.666,67/Triwulan. Biaya variabel yang terbesar terlihat pada biaya karung (untuk kompos (Rp. 340.000/Triwulan) dan untuk limbah biogas kering (Rp.232.000)) dengan biaya sebesar Rp $572.000 /$ Triwulan dan biaya terkecil untuk membeli tali rapia pada kedua proses kompos dan biogas (masing-masing Rp. 2.975 dan Rp. 2.030 per Triwulan) sebesar Rp.5005/Triwulan.

Tabel 1. Biaya Produksi Pengolah Limbah Ternak Sapi di Kecamatan Batang Asam.

\section{BIAYA TETAP}

\begin{tabular}{|c|c|c|c|}
\hline \multirow{2}{*}{ No. } & \multirow{2}{*}{ Nama Alat/Barang } & \multicolumn{2}{|c|}{ Biaya Tetap Masing-masing (Rp/Triwulan) } \\
\hline & & Kompos & Biogas \\
\hline 1 & Cangkul & 3.125 & 3.125 \\
\hline 2 & Skop & $1.973,68$ & $1.973,68$ \\
\hline 3 & Rumah Kompos & $125.000,01$ & 0 \\
\hline 4 & Jerigen & & 15.000 \\
\hline 5 & Tangki Biogas & & 25.000 \\
\hline 6 & Bak Fiber & & 135.000 \\
\hline 7 & Bak Semen & & $2.666,67$ \\
\hline 8 & Ember & & 11.250 \\
\hline 9 & Selang Biogas & & $24.456,52$ \\
\hline 10 & Pipa Air & & $10.956,52$ \\
\hline 11 & Mesin Air & & 18.750 \\
\hline & Jumlah & $130.098,69^{1}$ & $243.079,71^{3}$ \\
\hline
\end{tabular}

\section{BIAYA VARIABEL}

\begin{tabular}{llrr}
\hline \multirow{2}{*}{ No } & Nama Alat/Barang & \multicolumn{2}{c}{ Biaya Variabel (Rp/Triwulan) } \\
\cline { 3 - 4 } & & Kompos & Biogas \\
\hline 1 & Karung & 340.000 & 232.000 \\
\hline 2 & Tali & 2.975 & 2.030 \\
\hline 3 & Dekomposer & 62.500 & 0 \\
\hline 4 & Listrik & & $87.609,6$ \\
\hline & Jumlah & $405.475^{2}$ & $321.639,6^{4}$ \\
\hline
\end{tabular}

\section{Jumlah Total Biaya Produksi :}

Kompos $1+2$

$535.573,69^{\mathrm{a}}$

Biogas $3+4$

$564.719,31^{\mathrm{b}}$

Sumber: Data Olahan Primer, 2018

BIAYA TOTAL PRODUKSI ( pengolah limbah ternak) $(a+b)=$ Rp.1.100.293/Triwulan. 


\section{Jurnal Media Agribisnis Vol. 4 No. 1 Tahun 2019 Hal 1 - 9}

Media Komunikasi Hasil Penelitian Bidang Ilmu Agribisnis

ISSN print 2548-7027

ISSN online 2541-6898

\section{Pendapatan Pengolahan Limbah Ternak Sapi}

Besarnya penerimaan pengolahan limbah ternak sapi tergantung pada kuantitas dan harga jual produk. Penerimaan dalam pengelolaan limbah ternak ini terdiri dari 4 jenis yaitu kompos, limbah biogas kering, limbah biogas cair dan biogas. Nilai biogas yang dihasilkan disetarakan dengan nilai penggunaan tabung gas LPG $3 \mathrm{Kg}$ /Triwulan. Harga penjualan kompos di daerah penelitian adalah Rp.500/Kg, harga gas LPG $3 \mathrm{Kg}$ adalah sebesar Rp.20.000/Tabung harga limbah biogas kering adalah sebesar Rp.1.000/Kg, dan limbah biogas cair adalah sebesar Rp.10.000/Liter untuk lebih jelasnya dapat dilihat pada Tabel 2 berikut :

Tabel 2. Penerimaan Pengolahan Limbah Ternak Sapi di Kecamatan Batang Asam.

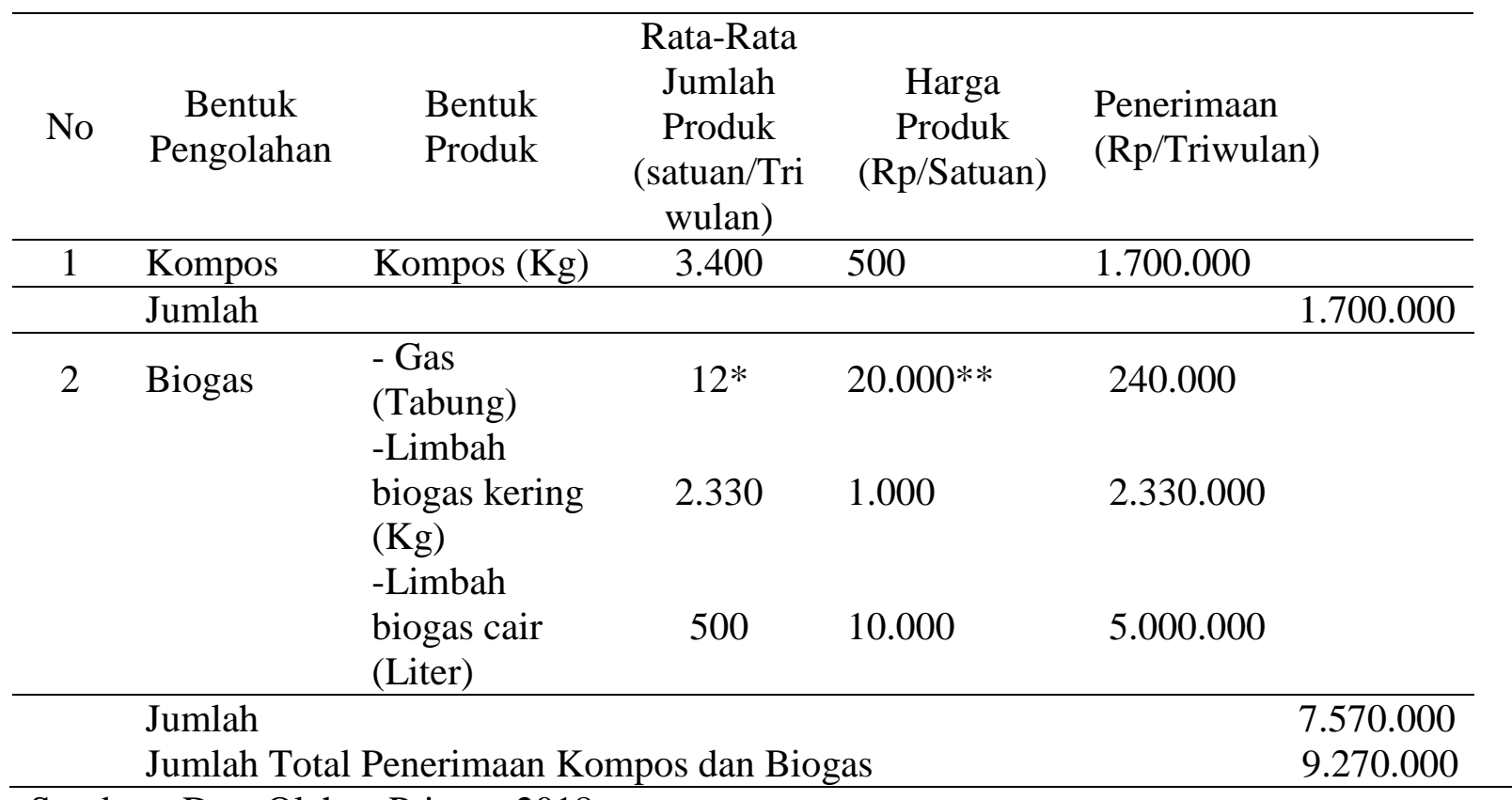

Sumber : Data Olahan Primer, 2018

* Produk biogas yang setara dengan 12 tabung gas LPG $3 \mathrm{~kg}$

** Harga 1 tabung gas LPG $3 \mathrm{~kg}$ sebesar Rp 20.000

Pendapatan pengolah limbah ternak sapi adalah total penerimaan dikurang total biaya produksi. 
Jurnal Media Agribisnis Vol. 4 No. 1 Tahun 2019 Hal 1 - 9

Media Komunikasi Hasil Penelitian Bidang Ilmu Agribisnis

ISSN print 2548-7027

ISSN online 2541-6898

\begin{tabular}{|c|c|c|c|}
\hline \multirow{2}{*}{ No. } & \multirow[b]{2}{*}{ Jenis Variabel } & \multicolumn{2}{|c|}{ Pendapatan } \\
\hline & & (Rp/Triwulan) & (Rp/Bulan) \\
\hline \multirow[t]{4}{*}{1} & Penerimaan & & \\
\hline & a. Kompos & 1.700 .000 & $566.666,67$ \\
\hline & b. Biogas & 7.570 .000 & $2.523 .333,33$ \\
\hline & Jumlah penerimaan & 9.270 .000 & 3.090 .000 \\
\hline \multirow[t]{4}{*}{2} & Total Biaya & & \\
\hline & a. Kompos & $535.573,69$ & 178.524 .56 \\
\hline & b. Biogas & $564.719,31$ & $188.239,77$ \\
\hline & Jumlah Total Biaya & $1.100 .293,00$ & $366.764,33$ \\
\hline \multirow[t]{4}{*}{3} & Pendapatan & & \\
\hline & a. Kompos & $1.164 .426,31$ & $388.142,10$ \\
\hline & b. Biogas & 7.005 .280 .69 & $2.333 .093,56$ \\
\hline & Jumlah Pendapatan & $8.169 .707,00$ & $2.721 .235,66$ \\
\hline
\end{tabular}

Sumber : Data Olahan Primer, 2018

Penerimaan kompos dalam triwulan yang diterima sebesar Rp.1.700.000/Triwulan sedangkan penerimaan biogas (termasuk limbahnya) sebesar Rp.7.570.000/Triwulan maka total penerimaan sebear Rp 9.270.000/Triwulan. Total biaya dalam pengelolaan limbah ternak sebesar Rp 1.100.293/Triwulan maka pendapatan pengelolaan limbah ternak sapi adalah $\mathrm{Rp}$. 8.169.707,00/Triwulan. Nilai tersebut biogas) setara dengan $\mathrm{Rp}$ 2.721.235,66/bulan. Pada jumlah anggota keluarga 3 orang maka pendapatan per kapita adalah sebesar Rp.757.078,55/bulan. Bila keluarganya hanya mengandalkan penghidupan hanya dari hasil usaha pengolahan limbah maka menunjukkan ketidaklayakan dimana pendapatan per kapitanya jauh di bawah UMR Kabupaten Tanjung Jabung Barat (Rp 2.280.249,66 (anonim.(2019)). Untuk lebih jelas dapat dilihat pada Tabel 3.

\section{KESIMPULAN}

Berdasarkan penelitian dan pembahasan dapat di tarik kesimpulan sebagai berikut :

1. Pengolahan limbah ternak sapi memerlukan peralatan sebagai berikut : cangkul, skop, galon, selang, ember, dan drum. Selain itu juga memerlukan sarana seperti, rumah kompos dan tangki biogas. Alat-alat tersebut berasal dari pembelian oleh pengolah limbah ternak sapi. Modal yang digunakan dalam pengolahan limbah ternak sapi yaitu modal sendiri dari hasil tabungan. Lahan yang digunakan untuk pengolahan limbah ternak sapi berstatus lahan sendiri dengan jumlah tenaga kerja 2 orang yang terdiri dari pemilik peternakan itu sendiri dan istrinya. Jenis produk yang dihasilkan :kompos,biogas,limbah biogas kering, dan limbah biogas cair. Kompos yang dihasilkan mencapai kuantitas sebesar $\pm 1.134 \mathrm{Kg} /$ Triwulan yang dijual dengan harga $\mathrm{Rp} .500 / \mathrm{Kg}$. Limbah biogas cair dijual dalam kemasan jerigen dengan harga $\mathrm{Rp}$. 10.000/liter. Sedangkan limbah biogas kering dijual dalam kemasan karung

Diterbitkan oleh Program Studi Agribisnis Fakultas Pertanian Universitas Batanghari Jambi Halaman 8 


\section{Jurnal Media Agribisnis Vol. 4 No. 1 Tahun 2019 Hal 1 - 9}

Media Komunikasi Hasil Penelitian Bidang Ilmu Agribisnis

ISSN print 2548-7027

ISSN online 2541-6898

dengan harga Rp. 1000/kg. Sistem penjualan limbah baik limbah biogas cair maupun kering tersebut dilakukan dengan cara sistem jemput oleh konsumen langsung.Biaya Triwulan yang dikeluarkan dalam pengolahan limbah ternak sapi yaitu dengan Total biaya Rp 1.105.391,68/Triwulan Biaya tetap pada kompos sebesar Rp 340.000 /Triwulan.

2. Pendapatan kompos dan biogas masing masing sebesar Rp 1.164.426,31/Triwulan dan $\mathrm{Rp}$ 7.005.280.69/Triwulan sehingga rata-rata pendapatan (kompos dan biogas) sebesar Rp 8.169.707,00/Triwulan. Pendapatan total ini setara dengan Rp. 2.721.235,66/Bulan.

\section{DAFTAR PUSTAKA}

Boediono. 1992. Pengantar Ilmu Ekonomi. Seri Sinopsis. BPFE Gajah Mada. Yogyakarta.

BPS. 2017. Popuasi Sapi Indonesia. Badan Pusat Statistik.

Hambali,E.,S. Mujdalifah, A. H. Tambunan, A. W. Pattiwiri dan R. Hendroko. 2008 Teknologi Bioenergi. Agro Media. Jakarta.

Haryati. T. 2006. Limbah Pertenakan Yang Menjadi Sumber Energi. Volume. 16 Nomor. 160 ISSN : 1024- 3100.

Muhamad Agus Setiadi, Gumbira Sa'id dan Kurnia Achjadi. 2012 Sapi Dari Hulu Ke Hilir dan Info Mancanegara. Agrifio (Penebar Swadaya Grup). Jakarta.

Sihombing. 2000. Teknik Pengolahan Limbah Kegiatan atau Usaha Peternakan. Pusat Penelitian Lingkungan Hidup Lembaga Penelitian. Institut Pertanian Bogor. Bogor.

Soehadji. 1992. Kebijakan Pemerintah Dalam Pengembangan Industri Peternakan dan Penanganan limbah Peternakan. Direktorat Jenderal Peternakan Departemen Pertanian. Jakarta.

Sudarman, A dan Algifari. 2001. Ekonomi Mikro-Makro. BPFE, Yogyakarta.

Sudarkoco. 1992. Penggunaan Bahan Organik Pada Usaha Budi Tanaman Lahan Kering Serta Pengolahannya. IPB. Bogor. .

Wahyuni, Sri. 2009. Biogas. Penebar Swadaya. Jakarta.

Anonim.2019. Gaji UMP UMK UMR Jambi Provinsi Kabupaten Kota Jambi 2018 - 2019 https://www.dapurpendidikan.com/ump-umk-umr-jambi-provinsi-kabupatenkota-jambi 